\title{
Dimensi Hukum Pengawasan terhadap Penyelenggaraan Otonomi Daerah
}

\author{
Ridwan
}

\begin{abstract}
The regional autonomy should not be interpreted as the separation between regional and state authority extremely for the constitution has declared the unity stated clearly to maintain any public interest. In spreading out governing power into any levels the main position to hold the responsibility is laid down upon the government. It would be very necessary to classify the provincial rules in order to prevent court system from any distorsion. The government could dismiss any internal provincial affairs while Supreme Court could do so in any public interest or criminal law.
\end{abstract}

\section{Pendahuluan}

Salah satu prinsip negara hukum demokratis (democratische rechtsstaat) yang berbentuk negara kesatuan dan menganut prinsip desentralisasi adalah pemencaran. kekuasaan secara vertikal (verticale machtspreiding), yang melahirkan organ-organ negara tingkat lebih tinggi (hogere staatsorganen) dan organ-organ negara tingkat lebih rendah (lagere staatsorganen). Organ negara tingkat lebih rendah ini berbentuk satuan pemerintahan daerah, yang merupakan organ mandiri dan karena itu tidak memiliki hubungan hirarki dengan organ negara tingkat lebih tinggi, "die niet hierarchish ondergeschikt zijn aan het hogere niveau en die daarom een zekere de mate van zelfstandigheid bezziten".' Menurut Bagir Manan, badan-badan tersebut adalah badan yang mandiri, pendukung wewenang, tugas, dan tanggungjawab yang mandiri. Sebagai badan mandiri, organ-organ atau kelengkapan pemerintahan desentralisasi tidak berada dalam kedudukan hubungan berjenjang (hirarkis) dengan organ-organ satuan pemerintahan tingkat lebih atas. ${ }^{2}$ Kepada satuan pemerintahan daerah 'diberikan

IJ.B.J.M. ten Berge. 1996. Besturen door de Overheid. Deventer: W.E.J. Tjeenk Willink. HIm. 37.

"Bagir Manan. "Hubungan Antara Pusat dan Daerah Berdasarkan Asas Desentralisasi Menurut UUD 1945." Disertasi. Unpad. Bandung. 1990. HIm. 246. 
wewenang untuk menjalankan otonomi, yaitu kebebasan dan kemandirian (vrijheid en zelfstandigheid) : untuk mengatur dan mengurus sebagian urusan pemerintahan. ${ }^{3}$ Meskipun antara organ pemerintahan tingkat atas dan organ pemerintahan daerah tidak dalam kedudukan hubungan hirarkis dan penyelenggaraan urusan rumah tangga daerah (huishouding) bertumpu pada kebebasan dan kemandirian, namun dalam penyelenggaraan daerah selalu ada pengawasan yang dilakukan oleh organ pemerintahan tingkat lebih tinggi. Bahkan dapat dikatakan, tidak ada pemerintahan berotonomi tanpa pengawasan (geen otonomie zonder toezicht), padahal antara pengawasan dengan desentralisasi akan memungkinkan timbulnya spanning. ${ }^{4}$ Bila demikian halnya, apakah pengawasan diperlukan atau apakah pengawasan tidak bertentangan dengan esensi otonomi yaitu kebebasan dan kemandirian? Lalu bagaimanakah sistem dan mekanisme pengawasan berdasarkan UU No. 22 Tahun 1999 tentang Pemerintahan Daerah?

Di dalam Pasal 113 dan 114 ayat (1) UU No. 22 Tahun 1999 disebutkan; "Dalam rangka pengawasan, Peraturan Daerah-dan Keputusan Kepala Daerah disampaikan kepada Pemerintah selambat-lambatnya lima belas hari setelah ditetapkan", "Pemerintah dapat membatalkan Peraturan Daerah dan Keputusan Kepala Daerah yang bertentangan dengan kepentingan umum atau peraturan perundang-undangan yang lebih tinggi dan/ atau peraturan perundang-undangan lainnya". Peraturan Daerah dan Keputusan Kepala Daerah termasuk sebagai peraturan perundang-undangan, sesuai dengan . Penjelasan Pasal 1 angka 2 UU No. 5 Tahun 1986 tentang PTUN yang merumuskan peraturan perundang-undangan sebagai, "semua peraturan yang bersifat mengikat secara umum yang dikeluarkan oleh Badan - Penwakilan Rakyat bersama Pemerintah baik ditingkat pusat maupun ditingkat daerah, serta semua Keputusan Badan atau Pejabat Tata Usaha Negara, baik di tingkat pusat maupun di tingkat daerah, yang juga mengikat umum". Sebagai peraturan perundang-undangan seharusnya pembatalannya dilakukan oleh Mahkamah Agung, sesuai dengan Pasal 5 ayat (2) Tap MPR No. III/MPR/2000 tentang Sumber Hukum dan Tata Urutan Peraturan Perundang-undangan, yang menegaskan bahwa "Mahkamah Agung berwenang menguji peraturan perundang-undangan di bawah undang-undang". Ketentuan bahwa Mahkamah Agung berwenang menguji secara materiil peraturan perundang-undangan di bawah undang-undang terdapat pula dalam Pasal 26 UU No. 14 Tahun 1970 yang telah dirubah dengan UU No. 35 Tahun 1999 tentang Ketentuan-ketentuan Pokok Kekuasaan Kehakiman; "Mahkamah Agung berwenang untuk menyatakan tidak sah semua peraturan perundang-undangan dari tingkat yang lebih rendah dari undang-undang atas alasan bertentangan dengan peraturan perundangundangan yang lebih tinggi". Ketentuan yang

${ }^{3}$ Bagir Manan. 1993. Perjalanan Historis Pasal 18 UUD 1945. Karawang: Unsika. HIm. 2.

${ }^{4} P$. de Haan, et.al. 1986. Bestuursrecht in de Sociale Rechtsstaat. Kluwer-Deventer: Deel:2. HIm. 161. 
sama juga terdapat dalam Pasal 31 ayat (1) UU No. 14 Tahun 1985 tentang Mahkamah Agung; "Mahkamah Agung mempunyai wewenang menguji secara materiil hanya terhadap peraturan perundang-undangan di bawah undang-undang". Berdasarkan ketentuan pasal-pasal ini apakah pembatalan Peraturan Daerah dan Keputusan Kepala Daerah yang dilakukan oleh Pemerintah dapat dibenarkan secara hukum?

\section{Ruang Lingkup Kewenangan Daerah}

Secara institusional Daerah Otonom adalah organ kenegaraan tingkat lebih rendah yang lahir dari prinsip pemencaran kekuasaan (spreiding van machten), sedangkan secara fungsional Daerah Otonom lahir dari prinsip pemencaran wewenang pemerintahan (spreiding van overheidsbevoegdheden), yang berarti hanya menjalankan urusan pemerintahan atau administrasi negara. Menurut Bagir Manan, meskipun otonomi bersifat staatsrechtelijk, tetapi isi urusan rumah tangga Daerah Otonom hanya mengenai fungsi pemerintahan atau fungsi administrasi negara. Kalaupun ada fungsi legislasi, hanya terbatas pada pengaturan di bidang administrasi negara. Itupun hanya terbatas pada penyelenggaraan urusan rumah tangga daerah. Daerah Otonom juga tidak berwenang membuat aturan ketatanegaraan atau aturanaturan lain yang bersifat kenegaraan.
Peradilan bersifat ketatanegaraan, karena itu tidak dapat menjadi wewenang Daerah Otonom. ${ }^{5}$ Pemberian wewenang Daeah Otonom yang terbatas pada bidang pemerintahan atau administrasi negara ini sejalan dengan semangat UUD 1945 yang tidak menghendaki "negara" di atas negara; "oleh karena Negara Indonesia itu suatu eenheidsstaat, maka Indonesia tidak akan mempunyai Daerah dalam lingkungannya yang bersifat staat juga".

Dalam kegiatan kenegaraan dan pemerintahan, kewenangan pemerintahan (bestuursbevoegheid) memiliki kedudukan penting, karena hampir semua kegiatan operasional kenegaraan dan kedaerahan bertumpu kepadanya. Bahkan dapat dikatakan bahwa bergerak atau diamnya kegiatan negara dan pemerintahan sangat bergantung pada ada tidaknya wewenang pemerintahan. Begitu pentingnya kedudukan wewenang pemerintahan, sehingga Stroink dan Steenbeek menyebutnya sebagai konsep inti dalam hukum tata negara dan. hukum administrasi; "het begrip bevoegdheid is dan ook een kernbegrip in het staats-en administratief rechf'. ${ }^{6}$ Begitu pentingnya pula wewenang pemerintahan ini, sehingga perlu dipencarkan melalui desentralisasi agar wewenang pemerintahan tidak terpusat pada satu tangan atau lembaga yang dapat menimbulkan tirani, "de overheidsbevoegdheden mogen niet

${ }^{5}$ Bagir Manan. "Wewenang Propinsi, Kabupaten, dan Kota dalam Rangka Otonomi Daerah." Makalah pada Seminar Nasional Pengembangan Wilayah dan Pengelolaan Sumberdaya Alam di Kawasan Pesisir. Bandung. 13 Mei 2000. HIm. 4-5.

${ }^{6}$ F.A.M. Stroink en J.G. Steenbeek. 1985. Inleiding in het Staats-en Administratief Recht. Tjeenk Willink. Aan den Rijn: Samsom H.D. Hlm. 26. 
geconentreed zijn in een hand, maar moeten verdeel worden over verschillende organen, die elkaar controleren en in evenwicht houden" (wewenang pemerintah tidak boleh dipusatkan ada satu tangan, tetapi harus dibagi-bagi pada organ-organ yang berbeda, yang masing-masing saling mengawasi untuk menjaga keseimbangan).

Dalam perspektif hukum, kewenangan pemerintahan berarti, "het vermogen om positief recht vast te stellen en aldus rechtsbetrekkingen tussen burgers onderling en tussen overheid en burgers te scheppen"8 (kemampuan untuk melaksanakan hukum hukum positif, dan dengan begitu dapat diciptakan hubungan hukum antara warga negara dan antara pemerintah dengan warga negara). Di dalam wewenang terkandung hakhak dan kewajiban-kewajiban, dengan kata lain "bevoegdheid dan ook verstaan als een samenhengen geheel van rechten en plichten" ${ }^{\text {" }}$ (wewenang diartikan sebagai hubungan-keseluruhan hak-hak dan kewajiban-kewajiban). Kewenangan yang di dalamnya terkandung hak dan kewajiban, menurut P. Nicolai adalah sebagai berikut:

"Het vermogen tot het verrichten van bepaalde rechtshandelingen (handelingen die op rechtsgevolg gericht zijn en dus ertoe strekken dat bepaalde rechtsgevolgen onstaan of teniet gaan). Een recht houdt in de (rechtens gegeven) vrijheid om een bepaalde feitelijke handeling te verrichten of na te laten, of de (rechtens gegeven) aanspraak op het verrichten van een handeling door een ander. Een plicht impliceert een verplichting om een bepaalde handeling te verrichten of na te laten". ${ }^{10}$

(Kemampuan untuk melakukan tindakan hukum tertentu (yaitu tindakan-tindakan yang dimaksudkan untuk menimbulkan akibat hukum, dan mencakup mengenai timbul dan lenyapnya akibat hukum tertentu). Hak berisi kebebasan untuk melakukan atau tindak melakukan tindakan tertentu atau menuntut pihak lain untuk melakukan tindakan tertentu, sedangkan kewajiban memuat keharusan untuk melakukan atau tidak melakukan tindakan tertentu).

Menurut Bagir Manan, wewenang dalam bahasa hukum tidak sama dengan kekuasaan (macht). Kekuasaan hanya menggambarkan hak untuk berbuat atau tidak berbuat. Dalam hukum, wewenang sekaligus berarti hak dan kewajiban. Dalam kaitan dengan otonomi daerah, hak mengandung pengertian kekuasaan untuk mengatur sendiri (zelfregelen) dan mengelola sendiri (zelfbesturen), sedangkan kewajiban secara horizontal berarti kekuasaan untuk menyelenggarakan pemerintahan sebagaimana mestinya. Vertikal berarti kekuasaan untuk menjalankan pemerintahan dalam satu tertib ikatan

'H.D. van WijkWillem Konijnenbelt. 1995. Hoofdstukken van Administratief Recht. Vuga, s'Gravenhage. HIIm. 41.

${ }^{8}$ F.P.C.L. Tonnaer. "Legaal Besturen; het Legaliteitsbeginsel." Toetssteen of Struikeiblok? Tulisan Dalam 1986. Besturen en Norm. Kluwer-Deventer: Bundel Opstellen Opgedragen aan R. Crince Le Roy. HIm. 265.

${ }^{9}$ F.A.M. Stroink en J.G. Steenbeek. Op. Cit. HIm. 27.

10P. Nicolai, et. al. 1994. Bestuursrecht. Amsterdam. HIm. 4. 
pemerintahan negara secara keseluruhan. ${ }^{11}$ Daerah Otonom memiliki wewenang pemerintahan melalui tiga cara; pertama, secara atribusi yaitu "de wet (in materiele zin) een bepaalde bevoegdheid aan een bepaald orgaan toekent"12 atau "toekenning van een bestuursbevoegdheid door wetgever aan een bestuursorgaan"13 (undang-undang (dalam arti materiil) menyerahkan wewenang tertentu kepada organ tertentu) atau (penyerahan wewenang pemerintahan oleh pembuat undang-undang kepada organ pemerintahan). Dengan kata lain, wewenang ini diperoleh langsung dari undang-undang; kedua, secara delegasi yaitu "te verstaan de overdracht van die bevoegdheid door het bestuursorgaan waaraan deze is gegeven, aan een ander orgaan, dat de overgedragen bevoegdheid als eigen bevoegdheid zal uitoefenen", ${ }^{14}$ (berarti pelimpahan wewenang oleh organ pemerintahan yang telah diberi wewenang, kepada organ lainnya, yang akan melaksanakan wewenang yang telah dilimpahkan itu sebagai wewenangnya sendiri). Wewenang delegasi ini terjadi ketika Daerah melaksanakan urusan yang berasal dari tugas pembantuan; ketiga, wewenang yang muncul dari prakarsa dan inisiatif sendiri dari masing-masing Daerah, seiring dengan kebebasan dan kemandirian yang dimilikinya.

"Bagir Manan, Wewenang..... Op. Cit. HIm. 1-2.

12“Algemene Bepalingen van Administratief Recht (ABAR)." Rapport van de Commissie inzake Algemene Bepalingen van Administratief Recht. Samsom H.D. Tjeenk Willink. Alphen aan den Rijn. 1984. HIm. 12.

${ }^{13}$ H.D. van Wijk/Willem Kinijnenbelt. Op. Cit. Hlm. 129.

${ }^{14}$ ABAR. Op. Cit. HIm. 27. 


\section{Kewenangan Daerah Otonom}

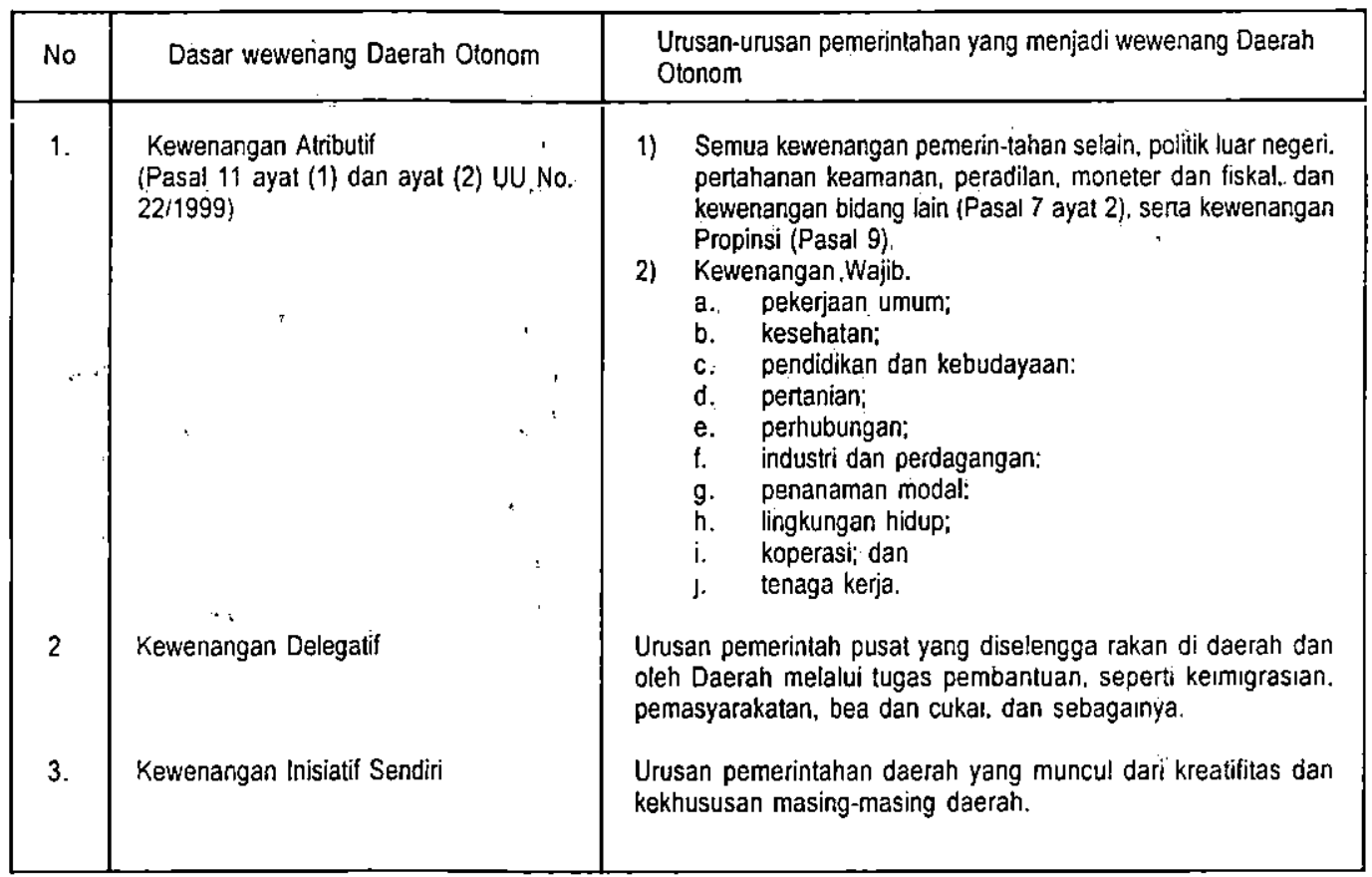

\section{Obyek Pengawasan}

Pengawasan yang dimaksud dalam tulisan ini hanya berkenaan dengan pengawasan terhadap pembuatan dan penetapan instrumen-instrumen hukum yang digunakan untuk mengatur dan melaksanakan urusan rumah tangga daerah. Ada tiga instrumen hukum utama yang digunakan yaitu Peraturan Daerah (verordening), Keputusan (besluit) Kepala Daerah, dan Ketetapan (beschikking) Kepala Daerah. Peraturan Daerah adalah produk hukum yang dibentuk oleh Kepala Daerah dan DPRD, sedangkan Keputusan Kepala Daerah adalah peraturan yang dibentuk oleh Kepala Daerah untuk melaksanakan Peraturan Daerah dan/atau atas kuasa peraturan perundang-undangan lain yang berlaku. Dalam bidang legislasi,
Kepala Daerah di samping berwenang untuk terlibat dalam pembentukan Peraturan Daerah, juga memiliki kewenangan mandiri untuk membuat peraturan perundangundangan. Secara teoretis dan praktis, dalam rangka menyelenggarakan urusan rumah tangga daerah, Kepala Daerah berwenang untuk melakukan berbagai tindakan hukum publik baik sepihak (eenzijdige) maupun beberapa pihak (meerzijdige) dengan menggunakan instrumen hukum. Khusus terhadap instrumen hukum yang digunakan dalam rangka tindakan hukum sepihak, Korsten dan Tonnaer mengatakan, "eenzijdige publiekrechtelijke rechtshandelingen worden verder wel onderverdeeld in besluiten van algemene strekking en beschikkingen. Deze 
besluiten zijn niet van geindividualiseerde, concrete aard en niet incidenteel. Besluiten van lagere openbare lichamen waarbij regels worden vastgestel. worden verordeningen genoem ${ }^{\prime \prime 15}$ (tindakan hukum publik sepihak ini selanjutnya dibagi dalam keputusan yang bersifat umum dan ketetapan-ketetapan. Keputusan yang bersifat umum bukanlah keputusan yang individual, bersifat konkret, dan insidental. Keputusan (seperti ini) yang ditetapkan oleh badan umum tingkat lebih rendah dinamakan peraturan perundangundangan). Keputusan jenis ini merupakan wujud dari regelend daad van de administratie (perbuatan pemerintah di bidang pengaturan) dalam negara hukum modern:

Dengan mendasarkan pada Peraturan Daerah dan Keputusan Kepala Daerah atau atas kuasa dari peraturan perundangundangan lain, Kepala Daerah dapat membuat ketetapan, yaitu sebagai keputusan yang tidak bersifat umum (besluit dat nief algemene strekking). Terhadap ketiga instrumen hukum tersebut, hanya Peraturan Daerah dan Keputusan Kepala Daerah yang menjadi obyek pengawasan organ pemerintah yang lebih tinggi, sementara Ketetapan (beschikking) Kepala Daerah menjadi wewenang PTUN.

\section{Urgensi Pengawasan terhadap} Penyelenggaraan Otonomi Daerah

Meskipun penyelenggaraan pemerintahan daerah bersandar pada kebebasan dan kemandirian; namun bukan dalam arti kemerdekaan (onafhankelijkheid) yang sejajar apalagi lepas dari ikatan negara kesatuan. Bagaimanapun juga, dalam suatu negara kesatuan, kedudukan hukum Daerah Otonom adalah sub sistem dari negara kesatuan. Sebagai sub sistem, penyelenggaraan pemerintahan daerah harus dalam kerangka keserasian dan keharmonisan dengan penyelenggaraan pemerintahan pusat. Guna menjaga keserasian dan keharmonisan hubungan antara kepentingan Negara Kesatuan dengan Daerah Otonom, maka diperlukan pengawasan oleh organ pemerintahan yang lebih tinggi. Menurut Irawan Soedjito, pengawasan dimaksudkan agar Daerah selalu melakukan tugas kewajibannya dengan sebaik-baiknya, sehingga terjamin kepentingan negara dan rakyat di daerah. Pengawasan adalah sebagian dari wewenang pemerintahan secara menyeluruh, karena pada tingkat terakhir Pemerintah Pusat-lah yang harus bertanggungjawab mengenai 'seluruh penyelenggaraan pemerintahan Negara dan Daerah. Hal-hal inilah yang membenarkan diadakannya pengawasan atas segala tindakan Daerah, karena keutuhan Negara Kesatuan harus terpelihara. ${ }^{16} \mathrm{Di}$ samping menjaga keutuhan negara kesatuan, ada beberapa alasan lain dilakukannya pengawasan; "een viffal motieven voor toezicht, te weten, het motief van de beleidsbewaking, het coordinatiemotief. het motief van de kwaliteitsbewaking, het financiele

${ }^{15}$ A.F.A. Korsten en F.P.C.L. Tonnaer. 1989. Lokale Regelgeving, in Lokale Bestuur in Nederland. W. Derksen en A.F.A. Korsten (redactie). Alphen aan den Rijn: Samsom H.D. Tjeenk Willink. HIm. 235.

${ }^{16}$ Irawan Soedjito. 1983. Pengawasan terhadap Peraturan Daerah dan Keputusan Kepala Daerah. Jakarta: Bina Aksara. HIm. 10-11. 
motief, en het motief van de rechts-en belangenbescherming van de burger" ${ }^{\prime 17}$ (ada lima alasan pengawasan, yaitu alasan untuk menjaga kebijaksanaan, alasan koordinasi. menjaga kualitas; alasan keuangan, dan untuk memberikan perlindungan hukum dan perlindungan kepentingan bagi warga negara). Pengawasan ditujukan sebagai instrumen untuk mengamati bahwa organ pemerintahan tingkat lebih rendah menjalankan tugasnya secara tepat dan dalam batas-batas tertentu sesuai dengan kebijakan pemerintah negara kesatuan. Pengawasan dibutuhkan untuk menjamin eksistensi negara kesatuan yang didesentralisir. Di samping itu, pengawasan juga digunakan untuk memberikan perlindungan terhadap warga negara, ${ }^{18}$ atau untuk kepentingan koordinasi dan integrasi pemerintahan, pengawasan penggunaan keuangan, serta perlindungan dan kepentingan warga negara..$^{19}$

\section{Macam-macam Pengawasan}

Di antara berbagai jenis pengawasan yang dikenal dalam kepustakaan dan praktek, hanya dua jenis pengawasan yang relevan dengan tulisan ini yaitu pengawasan preventif dan represif. Pengawasan preventif adalah pengawasan yang dilakukan sebelum keputusan atau peraturan efektif berlaku (voordat een besluit of regeling in werking kan treden). ${ }^{20}$ Pengawasan preventif ini berbentuk memberi pengesahan atau tidak memberi pengesahan. Sesuai dengan sifatnya, pengawasan preventif dilakukan sesudah keputusan Daerah ditetapkan, tetapi sebelum keputusan itu mulai berlaku. Dengan kata lain, suatu keputusan Daerah dalam arti luas. termasuk juga Peraturan Daerah, yang dikenai pengawasan preventif hanya dapat mulai berlaku, apabila keputusan itu telah lebih dahulu disahkan oleh penguasa yang berwenang mengesahkan. ${ }^{21}$ Berdasarkan catatan P. de Haan, "voor een groot aantal bestuursbeslissingen in een beslissing van een hoger toezichthoudend bestuursorgaan nodig om aan de eerstgenoemde beslissingen rechtskracht te verlenen"22 (sebagian besar keputusan pemerintah - tingkat lebih rendah - membutuhkan penetapan terlebih dahulum dari organ pemerintahan yang lebih tinggi yang berwenang mengesahkan untuk kekuatan hukum keputusan tersebut). Ada beberapa bentuk dari pengawasan preventif ini yaitu pengesahan (goedkeuring), persetujuan (toestemming vooraf), pembebasan/ dispensasi (ontheffing), pemberian kuasa (machtiging), dan pernyataan tidak keberatan (verklaring van geen bezwaar). ${ }^{23} \mathrm{Di}$ antara

${ }^{17}$ P. de Haan, et.al. Op. Cit. HIm. 163, alasan yang hampir sama dikemukakan pula oleh J.B.J.M. ten Berge. Op. Cit. HIm. 350.

${ }^{18}$ C.J.N. Vversteden. 1984. Inleiding Algemeen Bestuursrecht, Alphen aan den Rijn: Samsom H.D. Tjeenk Willink. HIm: 224.

15P. Nicolai, et.al. Op. Cit. HIm. 641.

${ }^{20}$ R.J.H.M. Huisman. Algemeen Bestuursrecht. Amsterdam: Kobra.HIm. 9.

${ }^{21}$ Irawan Soedijto. Op. Cit. HIm. 12.

${ }^{22}$ P. de Haan, et.al. Op. Cit. HIm. 119.

${ }^{23}$ P. Nicolai, et.al. Op. Cit. HIm. 643. 
bentuk-bentuk pengawasan preventif ini, yang terpenting dalam kaitannya dengan pengawasan terhadap Peraturan Daerah dan Keputusan Kepalä Daerah adalah pengesahan, sebagai salah satu alat dimana pemerintah pusat mëngadakan pengawasan atas badan hukum publik bawahan. ${ }^{24}$ Pengesahan dilihat sebagai "recht van placet" atau hak yang dimiliki oleh organ yang lebih tinggi untuk mèngesahkan. atau tidak mengesahkan keputusan. ${ }^{25}$ Pengesahan diperlukan dengan alasan sebagai berikut:

a) Pengesahan merupakan perwujudan pengawasan (toezicht). Pengawasan itu sendiri merupakan salah šatu sendi sistem penyelenggäraań ' pemerintahan berotonòmi. Tiada sistem penyelenggaraan pemerintahian bérotonomi tanpa pengawasan.

b) Pengesahàn merúpakan perwujudan hak "plácet" yaitu hàk yàng ada pada satuan atau pejabat yang lebih tinggi tingkatannya untuk mencegah atau mengukutikan agar suatu keputusan satuan pemerintahan yang lebih rendah tingkatannnya mempunyai kekuatan mengikat.

c) Pengesahan dapat juga dipandang sebagai tindak lanjut dalam pembuatan Peraturan Daèrah atau keputusàn lain yang memerlukan pengesahan.

d) Pengesahan merupakan cará melakukan pemeriksaan (checking), dalam rangka mempertahankan peraturan perundangundangan yang lebih tinggi tingkatannya, kepentingän pemerintahan daerah lain yàng mungkin terkena (baik langśung maupun tidak langsung) dan lain sebagainya. ${ }^{26}$,

Pengawasan represif dilakukan sètelah suatu keputusan àtau peraturan perundang. undangan diberlakukan atau berkenaañ dengan keputusan-keputusañ organ lebih rendah yang telah mempunyai kekuatan hukum. ${ }^{2 ?}$ Pengawasan represif ini berwujud; a) mempertangguhkan berlakunya suàtu Peraturän Daerah dan/atau Keputusan Kepala Daerah; b) membatalkan suatu Peraturan Daerah dan/atau Keputusan Kepala Daerah. ${ }^{28}$ Pembatalan dilakukan jika Peraturān Daerah dan Keputusan Kepala. Daerah tertentu bertentangan dengan kepentingan umum atau bertentàngan dengan peraturan yang lebih tinggi, "vermietiging kan plaatsvinden wegens; a) strijd met de het recht, zelfs de wet in formele zin; b) strijd met het algemeen belang.". Pembatalan sering diterapkan dalam arti pembatalan spontan, yakni pembatalan atas dasar inisiatif sendiri dari organ yang

${ }^{24}$ N.E. Algra, et.al. 1983. Kamus istilah Hukum Fockema Andreae. Binacipta. Hlm. 174

${ }^{25}$ C.J.N. Versteden, Op. Cit. Him. 225.

${ }^{26}$ Bagir Manan. 1995. Sistem dan Teknik Pembuatañ Peraturan Perundang-undangan. Tingkat Daerah. Universitas Bandung: LPPM. HIm. 53-54.

${ }^{27}$ J.B.J.M. ten Berge. Op. Cit. HIm. 351.

${ }^{28}$ Irawan Soedjito. Op. Cit. HIm. 51.

${ }^{29}$ C.J.N. Versteden. Op. Cit. HIm. 232. 
berwenang menyatakan pembatalan, tanpa melalui proses peradilan. ${ }^{30}$ Pengawasan represif ini bersifat negatif, dalam arti organ pemerintahan yang lebih tinggi akan melakukan penundaan atau pembatalan Peraturan Daerah dan Keputusan Kepala Daerah ketika ditemukan bertentangan dengan kepentingan umum atau bertentangan dengan peraturan yang lebih tinggi.

Dalam berbagai literatur dan ketentuan hukum positif, kriteria untuk pengesahan, penundaan, dan pembatalan 'Peraturan Daerah dan Keputusan Kepala Daerah adalah bertentangan atau tidak dengan kepentingan umum atau peraturan perundang-undangan yang lebih tinggi. Dalam rangka tertib penyelenggaraan: pemerintahan daerah dan hubungannya dengan pemerintahan pusat dan/atau Daerah lain, semestinya dipertimbangkan pula aspek lain seperti apakah. Peraturan Daerah dan Keputusan Kepala Daerah itu mengatur atau tidak. urusanurusan di. luar ruang lingkup kewenangan Daerah, apakah Peraturan Daerah dan Keputusan Kepala Daerah tersebut dapat menimbulkan atau tidak menimbulkan dampak negatif terhadap daerah-daerah lainnya, dan apakah Peraturan Daerah dan Keputusan Kepala Daerah itu bertentangan atau tidak dengan kebijaksanaan umum negara atau pemerintah.

\section{Pengawasan Berdasarkan UU No. 22 Tahun 1999}

Telah disebutkan, ketentuan tentang pengawasan ini diatur dalam Pasal 113 UU
No. 22 Tahun 1999, dan mekanismenya diatur dalam Pasal 114 yaitu sebagai bérikut:

(1) Pemerintah dapat membatalkan Peraturan Daerah dan Keputusan Kepala Daerah yang bertentangan dengan kepentingan umum atau peraturan perundang-undangan yang lebih tinggi dan/atau peraturan perundang-undangan

"lainnya. :

(2). Keputusan pembatalan Peraturan Daerah dan Keputusan Kepala Daerah, sebagaimana dimaksud, pada ayat (1), diberitahukan kepada Daerah yang bersangkutan dengan menyebutkan alasan-alasannya.

(3) Selambat-lambatnya satu minggu setelah keputusan pembatalan Peraturan Daerah dan Keputusan Kepala' Daerah, sebagaimana dimaksud pada ayat (2), Peraturan Daerah dan Keputusan Kepala Daerah tersebut dibatalkan pelaksanaannya.

(4) Daerah yang tidak dapat menerima keputusan pembatalan Peraturan Daerah dan Keputusan Kepala Daerah, sebagaimana dimaksud pada ayat (2), dapat mengajukan keberatan kepada Mahkamah Agung setelah mengajukannya kepada Pemerintah.

Dalam Penjelasan Umum angka 10 tentang pembinaan dan pengawasan disebutkan sebagai berikut:

"Yang dimaksud dengan pembinäan adalah lebih ditekankan pada memfasilitasi dalam upaya memberdayakan Daerah

30/bid. Him. 231. 
Otonom, sedangkan pengawasan lebih ditekankan pada pengawasan represif untuk lebih memberikan kebebasan kepada Daerah Otonom dalam mengambil keputusan serta memberikan peran kepada DPRD dalam mewujudkan fungsinya sebagai badan pengawas terhadap pelaksanaan Otonomi Daerah. Karena itu, Peraturan Daerah yang ditetapkan Daerah Otonom tidak memerlukan pengesahan terlebih dahulu oleh pejabat yang berwenang".

Berbeda dengan UU No. 5 Tahun 1974, yang mengatur dan membagi pengawasan menjadi pengawasan preventif, pengawasan represif, dan pengawasan umum, UU No. 22 Tahun 1999 hanya mengatur tentang pengawasan represif. Mengapa undangundang ini tidàk mengatur pengáwasan umum dan pengawasan represif, sedangan undang-undang sebelumnya mengatur? Sebagaimana diketahui kedua undangundang ini lahir dalam situasi dan konfigurasi politik yang berbeda. Menurut Moh. Mahfud, hukum merupakan produk politik. Jika konfigurasi politik suatu negara bersifat demokratis, maka akan lahir produk hukum yang responsif/populistik, sedangkan jika konfigurasi politik suatu negara bersifat otoriter, maka akan lahir produk hukum yang konservatif/ortodok/elitis. ${ }^{31}$ UU No. 5 Tahun 1974 lahir dalam konfigurasi politik yang otoriter dan sentralistik. Oleh karena itu, undang-undang ini berwatak konservatif/ ortodok/elitis, yakni isinya lebih mencerminkan visi sosial elit politik, lebih mencerminkan keinginan pemerintah, bersifat positivisinstrumentalis yaitu menjadi alat pelaksanaan ideologi dan program negara. ${ }^{32}$ Salah satu wujud sentralistiknya UU No. 5 Tahun 1974 adalah pengawasan yang ketat bahkan berlebihan terhadap penyelenggaraan pemerintahan daerah. Sementara UU No. 22 Tahun' 1999 lahir dari konfigurasi politik yang lebih demokratis, sehingga undäng-undang ini tergolong atau bersifat responsif/populistik. Sebagai peraturan yang responsif, 'ia memberikan ruang yang luas bägi partisipäsi rakyat dengan pengawasan yang relatif longgar, yang hanya menekankan pada pengawasan represif. Dengan demikian dapat dipahami mengapa undang-undang ini tidak mengatur pengawasan preventif dan pengawasan umum.

Pengawasan preventif dan pengawasan umum mengindikasikan pembatasan bahkan pengekangan terhadap Daerah, karena itu dalam batas-batas tertentu akan bertentangan dengan esensi otonomi yaitu kebebasan dan kemandirian Daerah untuk mengatur sendiri (zelfregelen) dan mengurus sendiri (zelfbesturen) urusan rumah tangga daerah. Pengawasan represif bersifat negatif, yang hanya dilaksanakan ketika ada Peraturan Daerah atau Keputusan Kepala Daerah yang bertentangan dengan kepentingan umum atau peraturan perundang-undangan yang lebih tinggi. Sebagai pengawasan negatif, pengawasan represif tidak membatasi apalagi menghilangkan esensi otonomi:

${ }^{31}$ Moh. Mahfud. 1988. Politik Hukum di Indonesia. Jakarta: LP3ES. HIm. 15.

${ }^{32}$ lbid. HIm. 25. 


\section{Persoalan Hukum Penundaan dan Pembatalan}

Telah disebutkan, bahwa organ-organ atau kelengkapan pemerintahan desentralisasi tidak berada dalam kedudukan hubungan berjenjang (hirarkis) dengan organ-organ satuan pemerintahan tingkat lebih atas, dan Peraturan Daerah atau Keputusan Kepala Daerah dibuat atas dasar kebebasan dan kemandirian masing-masing Daerah Otonom, karena itu pada dasarnya organ pemerintahan yang lebih tinggi tidak berwenang mencampuri kewenangan Daerah Otonom. Akan tetapi, karena kedudukan hukum (rechtspositie) Daerah Otonom adalah sub sistem negara kesatuan dan otonomi (vrijheid en zelfstandigheid) bukan dalam arti kemerdekaan (onafhankelijkheid) yang lepas dari ikatan negara kesatuan, maka pengawasan terhadap penyelenggaraan pemerintahan daerah tidak dapat diabaikan. Bahkan dalam praktek pemerintahan, pengawasan yang berbentuk pembatalan spontan dianggap inheren pada organ pemerintahan yang lebih tinggi. Dengan kata lain, "de regering is bevoegdheid tot spontane vernietiging, maar is hiertoe niet verplicht" (pemerintah berwenang untuk melakukan pembatalan, namun dalam hal ini bukan keharusan) atau "vernietiging is een bevoegdheid, geen plicht" 33 (pembatalan adalah suatu kewenangan, bukan keharusan).

Penundaan dan pembatalan sebagai bentuk pengawasan represif sejak dahulu telah menjadi perdebatan para sarjana, karena dianggap sebagai kompetensi lembaga peradilan, bukan kompetensi pemerintahan. Telah disebutkan bahwa kewenangan untuk menguji peraturan perundang-undangan terletak pada Mahkamah Agung. Oleh karena itu, ketika pemerintah melakukan penundaan atau pembatalan peraturan perundangundangan berarti pemerintah melakukan tindakan peradilan atau telah mencampuri wewenang lembaga peradilan. Meskipun demikian, sepanjang sejarah pemerintahan praktek penundaan dan pembatalan oleh pemerintah ini telah dilakukan seperti di Romawi, Inggris, Perancis, Belanda, dan sebagainya. Lalu apa alasan "pembenar" dari tindakan pemerintahan dalam bidang peradilan ini atau bagaimanakah karakteristik dari wewenang pembatalan dan penundaan ini?

Sepanjang pengetahuan penulis, belum ada tulisan atau buku yang secara khusus mengulas masalah ini secara panjang lebar. Bahkan dalam ABAR sendiri yang menjadi rujukan utama hukum administrasi disebutkan; "uitvoerig beschouwingen over de aard van de bevoegdheid tot spontane vernietiging hier achiterwege blijven"34 (tidak dapat menyajikan ulasan detail mengenai karakteristik wewenang pembatalan spontan ini).

Sebenarnya alasan pembenar penundaan dan pembatalan ini dapat dilacak dari karakteristik penyelenggaraan pemerintahan daerah dalam negara kesatuan. Ada beberapa karektaristik yaitu; pertama, wewenang penyelenggaraan pemerintahan daerah

${ }^{33}$ P. Nicolai, et.al. Op. Cit. Hlm. 646. ABAR. Op. Cit. Hlm. 282. dan C.J.J. Versteden. Op. Cit. Hlm. 235. ${ }^{34}$ ABAR. Op. Cit. HIm. 281. 
muncul dari prinsip pemencaran wewenang pemerintahan, artinya dalam negara kesatuan pada dasarnya penyelenggaraan semua tugas-tugas pemerintahan negara menjadi tanggungjawab pemerintah pusat, namun untuk kepentingan efisiensi, efektifitas, dan tuntutan demokratisasi, tugas-tugas tersebut sebagian diserahkan pada satuan-satuan pemerintahan daerah, dan tanggungjawab secara keseluruhan tetap berada pada pemerintah pusat; kedua, pembuatan peraturan perundang-undangan tingkat daerah hanya berkenaan dengan fungsi pemerintahan atau urusan rumah tangga daerah. Satuan pemerintahan daerah tidak diperkenankan membuat aturan di luar ruang lingkup kewenangannya ataupun aturan yang bersifat kenegaraan; ketiga, kedudukan hukum Daerah adalah sub sistem dari negara kesatuan. Sebagai sub sistem, tugas-tugas dan kewenangan satuan pemerintahan daerah tidak dapat terlepas dari sistem dan kebijakan pemerintah dan negara; keempat, pengawasan dimaksudkan untuk koordinasi dan integrasi tugas-tugas dan kebijaksanaan pemerintahan secara keseluruhan. Berdasarkan beberapa karakteristik inilah pengawasan terhadap peraturan perundangundangan tingkat lebih rendah memiliki alasan pembenar.

Meskipun tindakan pemerintah untuk melakukan penundaan dan pembatalan ini memiliki alasan pembenar, namun karena tindakan demikian merupakan bidang peradilan, maka agar tidak terjadi pencampuradukan wewenang seharusnya sebelum dilakukan penundaan dan pembatalan itu terlebih dahulu dilakukan klasifikasi peraturan perundang-undangan tingkat daerah. Peraturan Daerah dan
Keputusan Kepala Daerah yang hanya mengatur urusan intern pemerintahan, pembatalan dan penundaannya dapat dilakukan langsung oleh pemerintah, ketika ditemukan bertentangan dengan peraturan perundang-undangan yang lebih tinggi. Sedangkan Peraturan Daerah dan Keputusan Kepala Daerah yang memuat ketentuan sanksi pidana, berkenaan dengan kepentingan umum, ataupun pemberian beban kepada masyarakat, maka penundaan dan pembatalannya tidak dilakukan sendiri oleh pemerintah, tetapi oleh lembaga peradilan. Dengan kata lain, dalam rangka pengawasan represif ini, pemerintah hanya menunjukan dan memperingatkan bahwa Peraturan Daerah dan Keputusan Kepala Daerah tertentu bertentangan dengan peraturan yang lebih tinggi atau bertentangan dengan kepentingan umum, lalu memerintahkan kepada Daerah yang bersangkutan untuk merubahnya. Jika Daerah yang bersangkutan tidak mau merubah, pemerintah menyampaikan kepada Mahkamah Agung.

\section{Simpulan}

Dalam negara kesatuan yang berdesentralisasi, kedudukan hukum Daerah Otonom adalah sebagai sub sistem. Oleh karena itu kebebasan dan kemandirian satuan pemerintahan daerah dalam menyelenggarakan urusan rumah tangga daerah bukan berarti kemerdekaan yang lepas dari ikatan negara kesatuan. Untuk kepentingan koordinasi dan kesesuaian dengan kebijakan pemertintah dan negara, untuk menjamin prinsip taat asas peraturan perundang-undangan, serta untuk perlindungan hukum dan kepentingan umum, pengawasan senantiasa diperlukan. 
Peraturan Daerah dan Keputusan Kepala Daerah hanya diperkenankan mengatur urusan pemerintahan atau urusan rumah tangga daerah, yang merupakan realisasi dari prinsip pemencaran wewenang pemerintahan. Dalam pemencaran wewenang pemerintahan, tanggungjawab terakhir seluruh penggunaan wewenang untuk menyelenggarakan urusan pemerintahan tetap berada pada pemerintah, karena itu secara yuridis pemerintah berwenang melakukan penundaan dan pembatalan peraturan tingkat daerah yang bertentangan dengan kepentingan umum dan peraturan yang lebih tinggi. Meskipun demikian, agar tidak terjadi pencampuradukan wewenang dengan lembaga peradilan, maka sebelum dilakukan penundaan dan pembatalan terlebih dahulu dilakukan klasifikasi peraturan perundangundang tingkat daerah, yang hanya mengatur persolan intern pemerintahan daerah dapat langsung dibatalkan atau ditunda oleh pemerintah, jika ditemukan bertentangan dengan peraturan yang lebih tinggi atau kepentingan umum, sadangkan yang menyangkut kepentingan masyarakat dan ada sanksi pidana. maka pembatalan dan penundaanya melalui Mahkamah Agung. $\Xi$

\section{Daftar Pustaka}

"Algemene Bepalingen van Administratief Recht (ABAR)." Rapport van de Commissie inzake Algemene Bepalingen van Administratief Recht. Samsom H.D. Tjeenk Willink. Alphen aan den Rijn. 1984.

A.F.A. Korsten en F.P.C.L. Tonnaer. 1989. Lokale Regelgeving, in Lokale
Bestuur in Nederland. W. Derksen en A.F.A. Korsten (redactie). Alphen aan den Rijn: Samsom H.D. Tjeenk Willink.

Bagir Manan. "Hubungan Antara Pusat dan Daerah Berdasarkan Asas Desentralisasi Menurut UUD 1945." Disertasi. Unpad. Bandung. 1990.

. "Wewenang Propinsi, Kabupaten, dan Kota dalam Rangka Otonomi Daerah." Makalah pada Seminar Nasional Pengembangan Wilayah dan Pengelolaan Sumberdaya Alam di Kawasan Pesisir. Bandung. 13 Mei 2000.

1993. Perjalanan Historis Pasal 18 UUD 1945. Karawang: Unsika.

1995. Sistem dan Teknik Pembuatan Peraturan Perundang-undangan Tingkat Daerah. Universitas Bandung: LPPM.

C.J.N. Vversteden. 1984. Inleiding Algemeen Bestuursrecht, Alphen aan den Rijn: Samsom H.D. Tjeenk Willink.

F.A.M. Stroink en J.G. Steenbeek. 1985. Inleiding in het Staats-en Administratief Recht. Tjeenk Willink. Aan den Rijn: Samsom H.D.

F.P.C.L. Tonnaer. "Legaal Besturen; het Legaliteitsbeginsel." Toetssteen of Struikelblok? Tulisan Dalam 1986. Besturen en Norm. Kluwer - Deventer: Bundel Opstellen Opgedragen aan R. Crince Le Roy.

H.D. van Wijk/Willem Konijnenbelt. 1995. Hoofdstukken van Administratief Recht. Vuga, s'Gravenhage. 
Irawan Soedjito. 1983. Pengawasan terhadap Peraturan Daerah dan Keputusan Kepala Daerah. Jakarta: Bina Aksara.

J.B.J.M. ten Berge. 1996. Besturen door de Overheid. Deventer: W.E.J. Tjeenk Willink.

Moh. Mahfud. 1988. Politik Hukum di Indonesia. Jakarta: LP3ES.
N.E. Algra, et.al. 1983. Kamus Istilah Hukum Fockema Andreae. Binacipta.

P. de Haan, et.al. 1986. Bestuursrecht in de Sociale Rechtsstaat. KluwerDeventer: Deel 2.

P. Nicolai, et. al. 1994. Bestuursrecht. Amsterdam.

R.J.H.M. Huisman. Algemeen Bestuursrecht. Amsterdam: Kobra. 